\title{
From Pará to Brazil, João Francisco Madureira: a pioneer in Brazilian type design
}

\author{
Fernanda de O. Martins, \\ Edna Cunha Lima, \\ Guilherme Cunha Lima
}

\begin{abstract}
... And for them not to beg for stranger books, that were foreign to their reality and needs, I myself opened the punches, prepared characters, casted types, directed the machine's works, and lately I organized the Press getting it ready to work: only those familiar with the state of delay of the

Industry in Para can accurately assess the great difficulties I have overcome; one of the largest being the lack of means...

João Francisco Madureira, $1821^{1}$
\end{abstract}

\section{INTRODUCTION}

Printing authorization in Brazil were granted only after the arrival of the Portuguese royal family in 1808, with the installation of the Royal Press in Rio de Janeiro. From then on, the process of installing private printing workshops began in various parts of the country, especially after 1820, with the end of previous censorship in the period leading up to Brazil's independence. According to Rizzini (1945, p. 322), the printing shos that operated in the country before the independence were: that of Manoel António da Silva Serva, in Bahia, in 1811; that of Ricardo Rodrigues Castanho, in 1815 Recife, which only worked in 1817; the one installed in Maranhão by Governor Bernardo Silveira in 1821; and, that

1 Original Portuguese passage “...E para que não mendigassem dos Livros estranhos, que são raros as noções de que necessitassem, eu mesmo abri ponções, moldei os caracteres, fundi os Typos , e dirigi os trabalhos da Maquina, e ultimamente organisei a Imprensa pondo-a em estado de poder trabalhar: só quem conhece o estado de atrasamento em que se acha a Industria no Pará, poderá justamente avaliar as grandes dificuldades que venci; sendo huma das maiores, a falta de meios...” 
same year, the one set up by Daniel Garção de Melo in Belém do Pará; and two in Villa Rica, the Patrícia and the Provincial (Rizzini, 1945: 322). According to the author, the chronology indicates that the Province of Grão-Pará would have housed the fifth private typography to come into operation in Brazil.

This article presents the typography of João Francisco Madureira as the first typography to operate in Pará, in May 1821, even before the workshop that ran in Maranhão, imported from Lisbon. The new fact here is the revelation of a printed petition, presented by João Francisco Madureira on May 28, 1821, when he requests authorization to start printing services in the Pará Province.

Madureira, unlike the others, did not import from abroad a complete printing shop but built one himself without previous knowledge, based on the study of book prints. What makes his work more relevant, besides the construction of the press and other utensils to make the workshop feasible, is the fact that he planned, coined and cast the types needed to fulfill his objectives.

Rizzini's claim (1945), later reproduced by several authors, is based on the fact that Daniel Garção's workshop printed, in 1821, the first newspaper of the province, O Paraense, edited by Felipe Patroni. This newspaper can be easily found in libraries, thus suggesting it could be the inaugural document, when in fact it is not. We believe that this is the reason why contemporary historians, more concerned with the history of books or journalism, have dedicated only small paragraphs to Madureira's initiative.

In contrast Antônio Ladislao Baena (1838), who was a historian researcher contemporary to the typographer, considered the presence of a typography in the Province so important as to include it in his work, a historical narrative book about the significant moments in Pará between 1615 and 1823. Once the printed petition has been identified, it is possible to narrate the feats of João Francisco Madureira and finally give him due credit.

\section{THE FOUNDING OF LETTERPRESS SHOP IN PARÁ}

It is now possible to affirm that the first attempt to use type presses in Pará, as mentioned above, was João Francisco Madureira's, who, in 1821, without training or practical knowledge, presented to the Royal Provisional Board a dispatch printed in his own workshop, requesting a license to enter into the free exercise of printing.

João Francisco de Madureira (who later added to his surname the nickname Pará, and as such appears in several references) was born in October 12, 1797 in Vila do Acará, Pará. Abandoned by his parents, he was raised by an adoptive mother. In 1818, he obtained from the state Governor, Count of Vila Flor, the job 
position of accountant at the Royal Treasury Board. He also acted as acolyte chaplain at the Cathedral. He was an inventive man, and besides the typographic business, he obtained, by the end of the 1820s, from the part of D. Pedro I, incentive and materials to build a maritime device - without success, by all indications.

Madureira himself narrated the fact in the printed pamphlet "O despotismo desmascarado ou a verdade denodada dedicado ao memoravel dia $1 .^{\circ}$ de janeiro de 1821, em que a provincia do Grão-Pará deo principio á regeneração do Brazil offerecido ao soberano congreço da naçaõ portugueza pelo patriota paraense João Francisco de Madureira Pará, amanuence da contadoria da junta da fazenda nacional e real daquella provincia; e nascido na sua capital a 12 de outubro de 1797”, published in 1822 in Desiderio Marques Leão's Press, in Lisbon. (Figure 2)

According to Madureira (1822, p. 64), he asked the Government Board to release him from his services so he could devote to the execution of the printing press. Once the license was granted, he dedicated himself - with the collaboration of three carpenters and two goldsmiths -, in his own words, "I myself opened the punches, prepared characters, cast types, directed the machine's works, and lately I organized the Press getting it ready to work".

(...) Then I, filled with joy for the freedom of my country, and animated by a true Patriotism and the pure desire to be useful to all my fellow citizens, conceived the arduous project of arranging a letterpress; without having exercised any art or office, never having left my native country, having as companionship only my frail industry and the assiduous desire to be useful. Recognizing the urgent need we had for said letterpress, I demanded from the Government the necessary release from duty, to dedicate myself to its making, which was granted to me, as well as the assistance of three Arsenal Carpenters and two Train Goldsmiths to help me, for whom I paid their fees. I also begged for the faculty of ordering the making, in the train, of a steel piece which I need, not having found outside professionals who could do it perfectly and fast, and I paid it for this dutifully evaluation, which I was readily granted. (Madureira, 1822, p. 64-65) ${ }^{2}$

2 Original Portuguese passage: “(...)Então eu transportado de alegria pela liberdade da minha Patria, e animado de hum verdadeiro Patriotismo, e daquelles puros desejos com que devemos ser úteis a todos os nossos Concidadãos, concebi o árduo projecto de arranjar huma Typographia; sem haver exercido Arte ou Oficio algum, não tendo jámais sahido do meu Paiz natalicio, tendo só por companheiros a minha fraca industria, e assidua vontade de ser útil. Reconhecendo a urgente necessidade que della tínhamos, exigi do Governo a necessária dispensa do Serviço, para me empregar na 


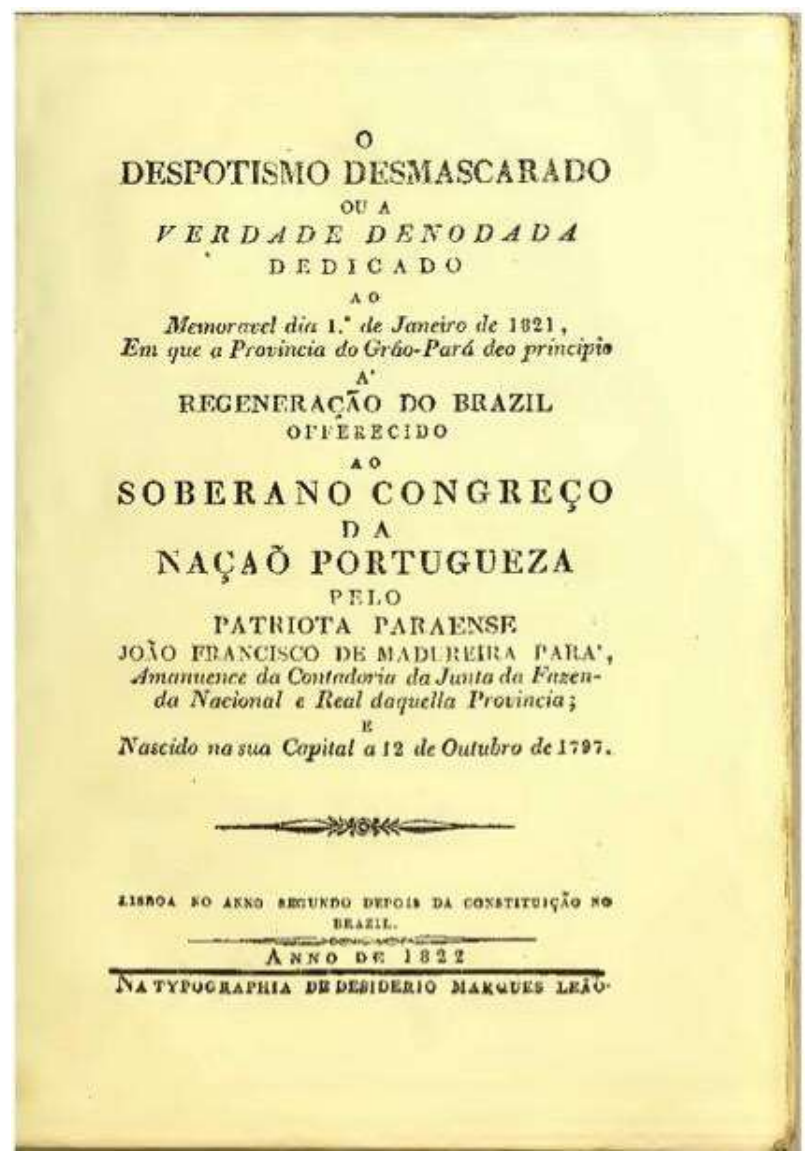

Image 1 - The Despotismo desmascarado, a João Francisco Madureira's phamphlet printed in Lisbon, 1822 (Source: https://repository.library.brown.edu/studio/item/ bdr:576116/PDF/?embed=true)

He further states that, having spent all his resources on this enterprise, he once again requested financial help from the government. Government's aid was denied, but he got financial support from a fellow citizen, Francisco Jozé Gomes Pinto:

factura da dita Typographia, o qual ma concedeo, como também o auxilio de trez Carpinteiros do Arcenal, e dous Ourives do Trem para me ajudarem, pagando-lhes eu os seus jornaes; implorei lambem a faculdade de mandar fazer no Trem uma pessa de aço que me era necessária por não achar Officiaes por fora que ma fizessem com perfeição e brevidade, pagando-a eu pela justa avaliação, o que me concederão prontamente". (Madureira,1822, p. 64-65) 
(...) I have dispossessed myself of all my own belonging. As this did not balance the expenses, I demanded via petition to the government to receive two-quarters of salary as an advance, the sum of my receivable wages; and the leave of absence agreement. I was honored to receive, by Order of March $28,1821 .=$ Considering the circumstances, two months of leave are granted; but not the rest of the requests. = seeing myself reduced to the last resources, I turned to Francisco Jozé Gomes Pinto, a businessman from the Plaza (after having already pleaded to some other people without success), and meritorious citizen (...). He did not hesitate to come see the machinery and, willing to protect it with all that was necessary, he gave me a hundred and twenty thousand reis with which I put it to work - so much so that I was able to complete a printed petition to the government, which showed that the letterpress printing shop was ready to work, for which I needed the competent License required to be able to enter into the free exercise of the workshop (...) (Madureira, 1822, p.65-66)

On May 28, 1821, he presented to the Governing Board a request printed on his own letterpress, in which he showed that it was ready to work, requiring the appropriate license to enter the free exercise of the workshop. The president and other Board members welcomed the news and praised Madureira, who even printed some ephemera papers from the government's file. According to him:

(...) I myself opened the punches, prepared characters, cast types, directed the machine's works, and lately I organized the Press getting it ready to work $(\ldots)$

3 Original Portuguese passage: “(...) desfis-me até, do que possuía inteiramente. e como isso não equilibrasse as despezas, exegi por hum Requerimento ao Governo me mandasse dár dois quartéis adiantados; a conta dos meus vencimentos: e refórma de Licença; o qual se dignou honrar- me com o Despacho de 28 de Março de 1821. = Attendidas as circunstancias consede-se dois mezes de Licença; quanto ao mais não pôde ser deferido. = vendo-me reduzido ao ultimo extremo, recorri a Francisco Jozé Gomes Pinto, negociante da Praça (depois de já haver recorrido a alguns infructiferamente) e Cidadão perfeitamente Benemérito, (...) o qual sem exitár vai vèr a obra, e tanto que a vio, prestes a protejèla com tudo o que fosse necessário, ministrou me cento e vinte mil reis com que a púz em termos de poder trabalhar, e tanto que pude fiz hum Requerimento Impresso ao Governo em que mostrava que a Typographia já podia trabalhar, para o que requeria a competente Licença para poder entrar no Livre exercício da Officina andc. (...)" (Madureira, 1822, p. 65-66) 
(...) Having after that the satisfaction of printing some documents for the Government Secretariat's files; and offering over a thousand copies to compatriots who gave me proof of esteem and friendship, and evaluating my circumstances of which they were fully aware, helped me with a spontaneous subscription, with which I could pay back my debts (...)" (Madureira, 1822$, p. 67$)^{4}$

As his license was not published, in September of the same year he filed a new request asking to be removed from his duties as an accountant. He travels to Lisbon in 1822 to apply for a license from the King and to learn about the art of printing.

(...) Since I had not obtained any answer to my requirement by September, and given the sad circumstances in which I saw the fruit of my tireless efforts, and experiences that will oblige me by the stimuli of honor, to implore the necessary License to come to Lisbon in order to require His Majesty's assistance, whom so many praise, for the benefit of my country. At the same time, I will educate myself in mechanisms and geometrical precepts related to the Typography, so as to be able to accurately continue its progress. I posed my Application, in which I begged for a year of leave of absence, not to harm the National Treasury. That leave will be granted by Order of September 26. (...) (Madureira, 1822, p. 73-74) ${ }^{5}$

4 Original Portuguese passages: “(...) Eu mesmo abri ponções, moldei os caracteres, fundi os Typos, e dirigi os trabalhos da Maquina, e ultimamente organisei a Imprensa pondo-a em estado de poder trabalhar. (...)

(...) Tendo após disto a satisfação de imprimir alguns papeis gratuitos para o espediente da Secretaria do mesmo Governo; e offerecer para mais de mil Impressos aos meus Compatriotas que deraõ me testemunhos, de estima e amisade, e avaliando as minhas circunstancias de que tinhão cabal conhecimento, e sem se exemirem prestaraõ-se a concorrencia de huma espontanea Subscripção, com a qual pude reçarcir o que devia(...)” (Madureira, 1822, p. 67)

5 Original Portuguese passage: “(...) Como já em Setembro não tivesse obtido Despacho algum do meu Requerimento, e attendendo as tristes circunstancias, em que via o fruto das minhas incansáveis applicações, e experiências que me obrigarão pelos estimulos da honra, a implorar a necessária Licença para vir a Lisboa, afim de gostar o auxílio de V. Magestade de que tantos se aprazem, em beneficio da minha chara Pátria; e ao mesmo tempo instruir me no mais fácil mecanismo, e preceitos geométricos, que sejão anexos a huma Typographia, para assim poder com exactidão continuar no progresso da mesma; fiz o meu Requerimento, em que para nâo lezar a Fazenda Nacional, 
The military man and historian Baena confirms, in his 1838 publication, Compêndio das Eras da Província do Pará (Image 2) that, on May 28, 1821, João Francisco Madureira Pará submitted a printed request to the Government Board, as follows:

Joao Francisco de Madureira Pará, native of the same country and accountant of the Treasury Board, presented to the provisional Government Board an application printed on a press that he himself organized, by opening the punches and preparing the alphabetical characters. For that, he had only studied some foreign prints, not ever having seen this kind of machine in person, nor having practical knowledge in the art of printing and the art of easily extracting numerous copies of written discourses. In the said request, he mentioned that, notwithstanding the lack of protection and necessary knowledge, he had tried to form a press his country lacked. Having almost finished the works, he made it available to the provisional Board, and asked that not only they grant him permission to start working, but that they also reward his enterprise, if it were deserving. Before such request, he had already pleaded the Board for subsidy with which the cover the expense of his typographic experiments: and obtaining insufficient means he turned to the merchant Francisco José Gomes Pinto, who saw the Press and soon gave him a hundred and twenty thousand reis. He later obtained a subscription from one hundred and eighteen people, adding up to seven hundred and eighty thousand two hundred and sixty reis. (BAENA.1838, p.526) ${ }^{6}$

implorava hum anno de Licença registada , a qual ma concederão por Despacho de 26 de Setembro. (...)" (Madureira, 1822, p. 73-74)

Original Portuguese passage: "Apresenta Joaõ Francisco de Madureira Pará, natural do mesmo paiz e Amanuense da Contadoria de Junta da Fazenda, à Junta provisoria do Governo um requerimento impresso em um prelo que elle mesmo organisou, abrindo os ponçoens moldando os caracteres alfabeticos, fundindo os typos e dirigindo o trabalho, só pelo estudo de algumas estampas estrangeiras, e naõ por ter visto este genero de maquina, nem por ter noçoens praticas da arte de imprimir isto he da arte de tirar facilmente numerosas copias dos discursos escriptos. No ditos requerimento expressou que naõ obstante a falta de proteção e de necessários conhecimentos tentara formar um prelo para suprir a carencia que delle tinha a sua patria: e que tendo a obra quase acabada a collocava sob o favor da Junta Provisória, e pedia que naõ só lhe concedesse licença para entrar no destinado lavor mais ainda que galardoasse a sua empreza se por ventura ella disso for merecedora. Ja antes deste requerimento elle havia supplicado a mesma junta subsidio em que se estribasse a despesa de seu ensaio Typografico: e obtendo meios que não podiao emparelhar com os gastos recorreio ao 


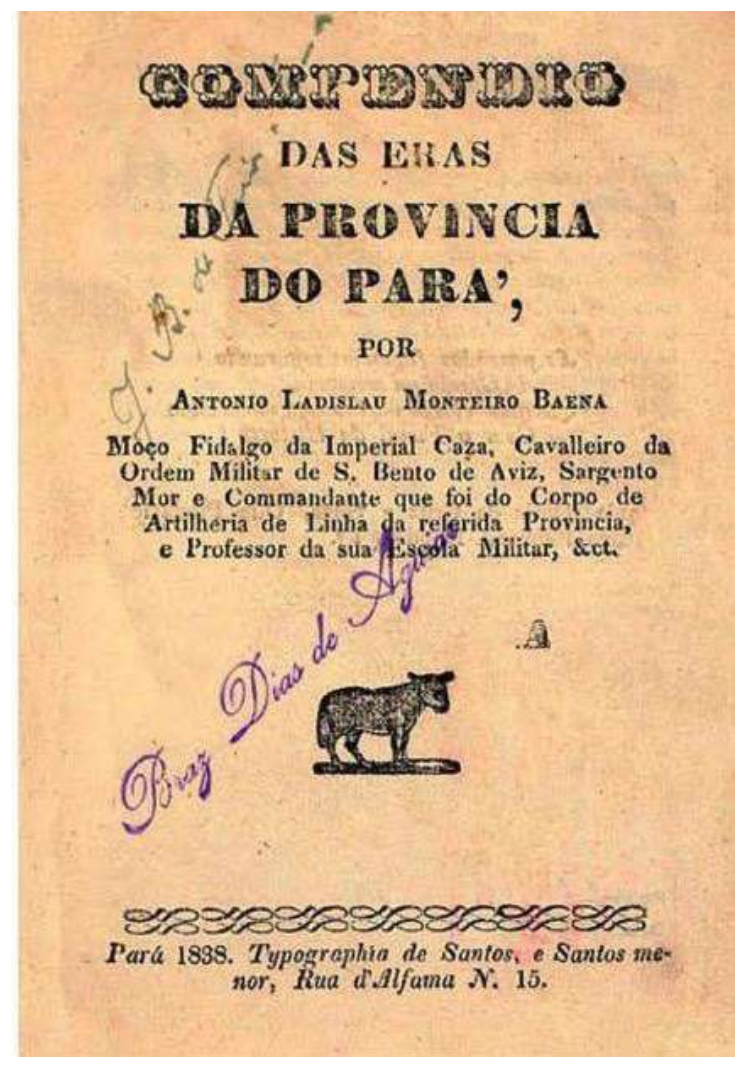

Image 2 - Compendio das Eras do Pará, book by Antonio Baena, title page - printed at the Santos and Santos Press, in 1838 (João Meirelles Collection)

The beginning of the 1820s is especially troubled in the province of Grão-Pará. Closely linked to Portugal, the Parenses believed that liberalism would include them, and stood in favor of Portugal's liberal revolution, against Brazil's Independence. Due to this complicated context, Madureira decides to travel to the King's Court to petition to D. João VI the necessary financial support for his workshop. It is important to note that Madureira stated that he had previously requested financing from the Provincial Government, and since it was insufficient, he had to obtain support from a merchant to complete his work and present said printed application.

negociante Francisco José Gomes Pinto, que vio a Imprensa e ministrou-lhe logo cento e vinte mil reis. Depois conseguio uma subscrpção de cento e dezoito pessoas, que composeraõ a quantia de sete centos e oitenta mil duzentos e sessenta reis". (BAENA.1838, p.526) 
It is also noteworthy that the typographic workshop actually operated for a short period, for in the same document the typographer tells that, after petitioning to the Governing Board, he even printed official documents and "over a thousand copies".

Even though Madureira had never left the Pará Province or seen a type shop before, it is clear thar he had a fair notion of the complexity of his initiative when he requested from the Board the assistance of three carpenters and two goldsmiths, as well as authorization to make a piece of steel "on the train". He also quotes that his requests were promptly answered, and that he personally paid for the services. He developed his letterpress "through observation and study of some prints that came to my knowledge", and at the end of this short experiment he realized that he needed more knowledge. Therefore, he requested the leave of absence to head to Lisbon and study "mechanisms and geometrical precepts related to the Typography, so as to be able to accurately continue its progress" (Madureira, 1822, p. 73). After his departure to Lisbon, nothing more is known about his connection to typography. Nevertheless, he continues to be an inventor, and in 1832 he conceives a navigation machine and obtains money from the emperor to build it.

The functioning of Madureira's letterpress is narrated by historians from Pará such as Antonio Baena (1838), Domingos Rayol (1865) and Manuel Barata (1908), and recounted by several historians such as Rizzini (1945, p. 325), Sodré (1966, p. 36), Hallewell 2005, p. 129,192) and, more recently, Molina (2015, p. 337) without, however, being recognized as the founding landmark of the history of printing in Pará. Material proof was necessary to corroborate his claims and reclaim the pioneer's place in history. Because he only printed ephemeral documents, it becomes more difficult to prove his groundbreaking nature through material references. It was only after many attempts of search in libraries, at the Public Archive of the State of Pará, in the National Library, and in the National Public Archive that we found, in the Brazilian Historical and Geographical Institute - IHGB, a copy of Madureira's requirement, definitely proving its existence and its pioneering nature.

\section{COULD THE EXISTENCE OF THE MADUREIRA LETTERPRESS BE POSSIBLE?}

The legal authorization of the printing press in our territory only occurred in 1808 , from equipment and professionals imported from Lisbon. When the access to printing technologies was allowed, they start being implanted at an intense pace - first in the Rio de Janeiro Court, and then in Salvador with Silva Serva. In a decade, the printing presses play an important role in the social and political scene of the colony. 
The graphic workshop played a significant role, though neglected, in combining intellectual and commercial activities, which mutually reinforced each other and thereby created a particularly powerful impulse, almost irresistible. (Eisenstein, 1998, p. 84)

In the early 19th century, a letterpress workshop in Brazil had a wooden press and type cases with a collection of sorts for texts in various sizes, including the largest for titles, emblems, lines for composition and other tools required. The main tasks involved in this sort of workshop are composition, revision, imposition, printing and finishing. Many of those could be executed by the same professional (as they were in the beginning), with the collaboration of assistants.

While printing material such as types, lines and embellishments needed to be imported, wooden presses could be built locally, as the necessary knowledge for it was accessible in old publications. The more complex type casting, however, required technical knowledge and larger skills, harder to grasp from studying old printings, such as the examples below, from Encyclopédie de Diderot et d'Alembert.

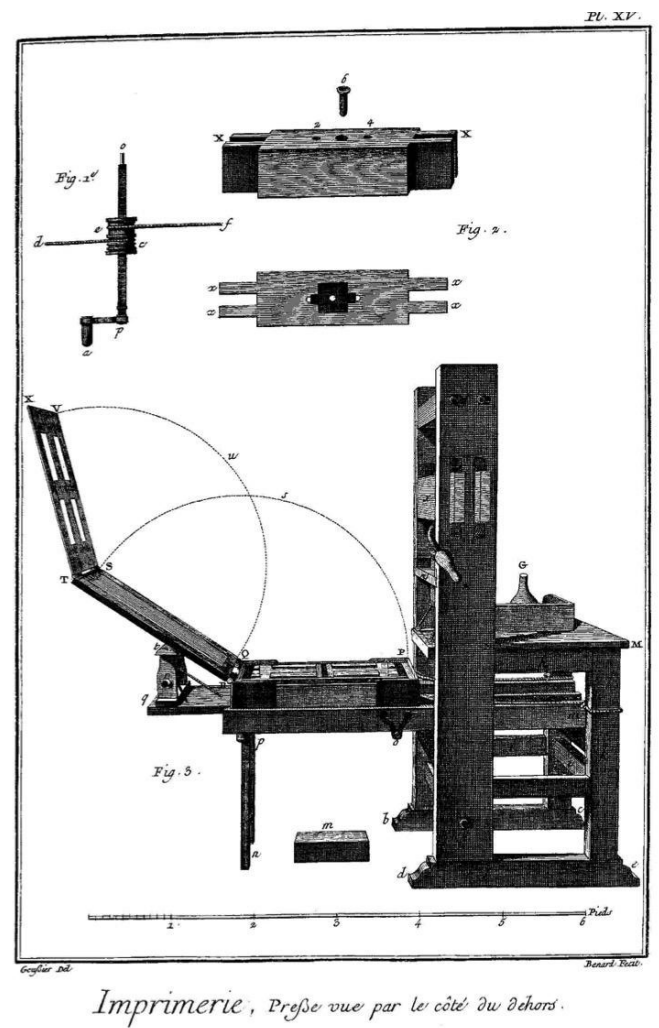

Image 3 - Press for typographic printing (source: Encyclopédie de Diderot et d'Alembert). 


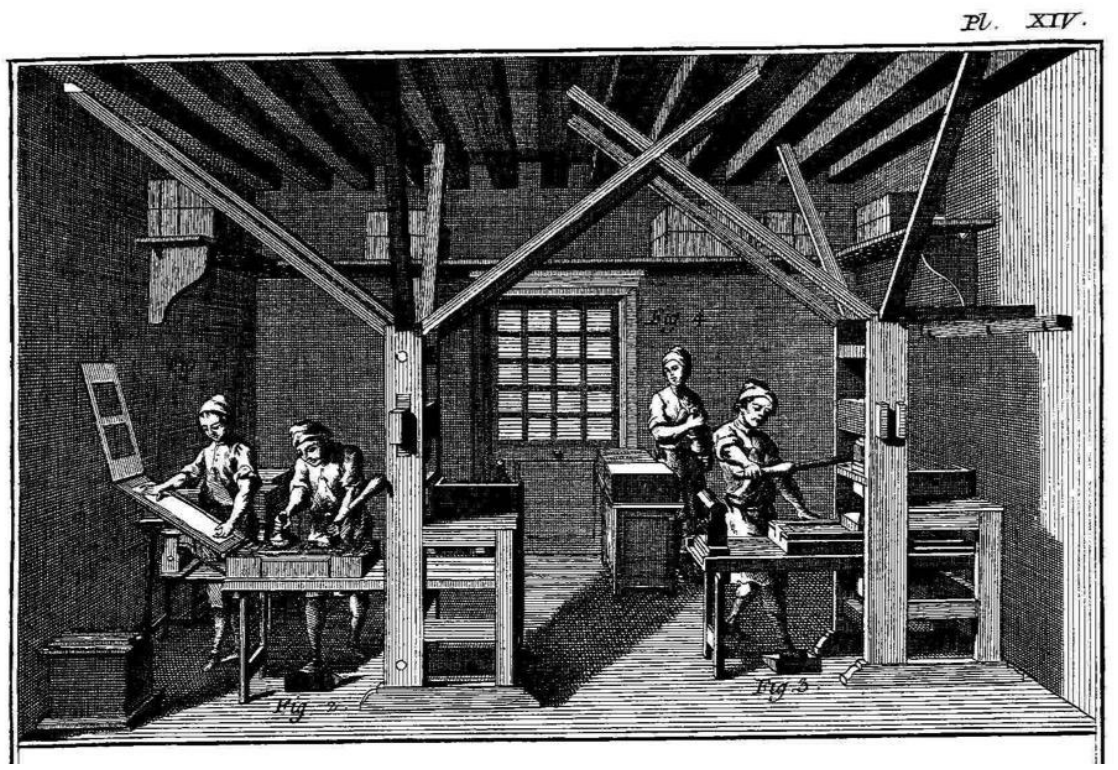

Image 4 - Typographic workshop (source: Encyclopédie de Diderot et d'Alembert).

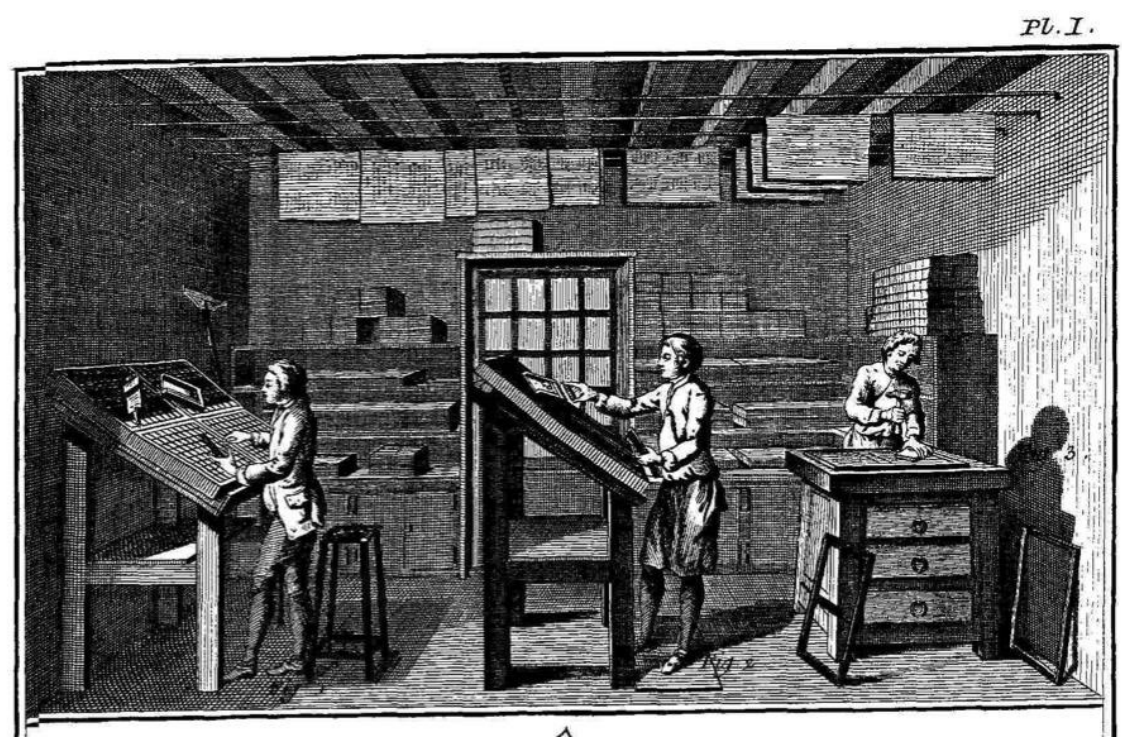

Image 5 - Area for typographic composition (fonte: Encyclopédie de Diderot et d'Alembert). 


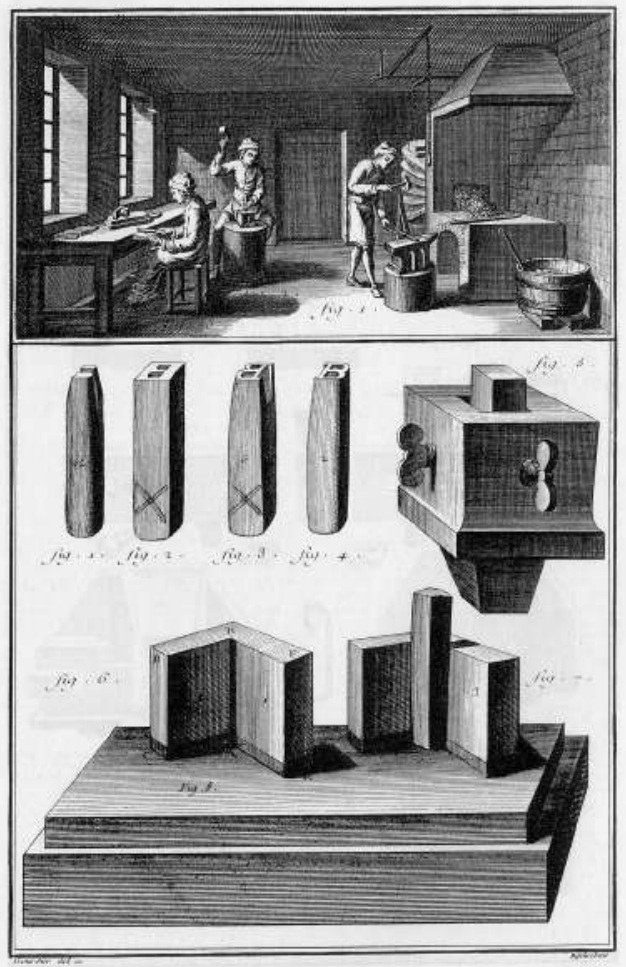

Fonderie en caracteres

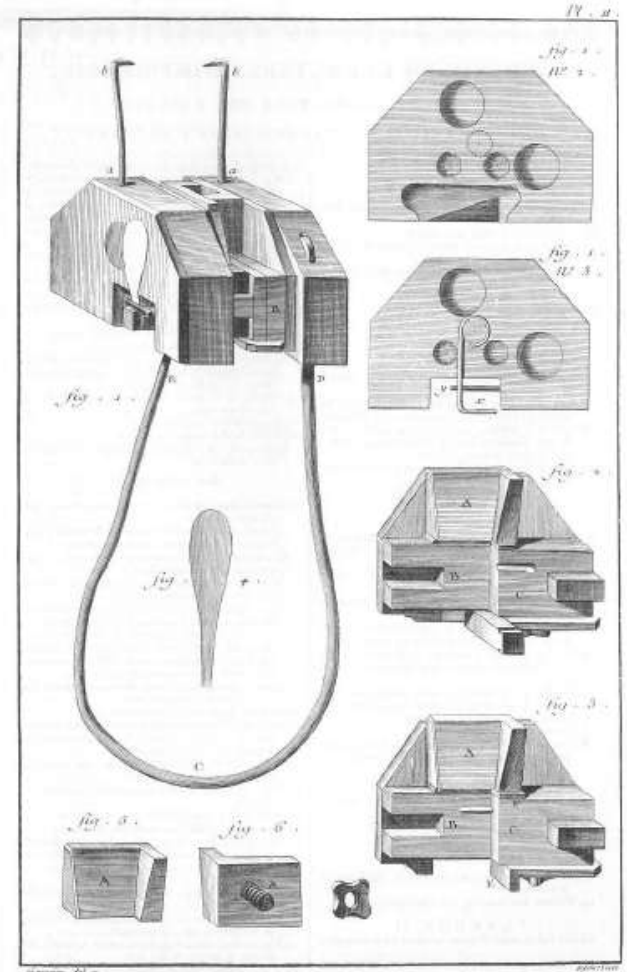

Fonderie on Caractere:

Image 6 - Casting of Types (source: Encyclopédie de Diderot et d'Alembert).

Authors who dedicate themselves to the history of books or to the printed culture weave their analysis from the book object, and therefore tend to ignore ephemeral prints. According to Edna Cunha Lima, it is common that the history of printing be delimited by the beginning of the production of books or newspapers, objects of greater prestige, obscuring the fact that the printing presses operated in the production of ephemeral prints for commerce, public administration or even playing cards.

Traditionally, even when it precedes other prints, the printing of ephemeral material is not usually regarded as the beginning of the press in western countries, which usually consider the inaugural date as that of the first book. However, other materials suitable for visual communication were already being mechanically duplicated without flaunt, for everyday use. Playing cards, for example, have a long history, of humble origin, in the field of fun and leisure. (Lima, 2000, p. 1) 
According to Hallewell (2005, p. 129), even before the arrival of the Royal Print, Father José Joaquim Viegas de Menezes printed in Villa Rica, in 1807, a 9-page booklet. The publication was of a poem dedicated to the Provincial Governor, engraved in a metal plate and printed in a press designed for domestic purposes. Viegas de Menezes, who as a student in Portugal had become friends with José Mariano da Conceição Veloso, manager of Arco do Cego Typography, had learned the art of engraving and printing. Thirteen years later, associated with the shoemaker Manuel José Barboza Pimenta e Sal, he built a complete letterpress, which according to the author was finished by the end of 1821 . He was only given license to operate in April 1822. The workshop, named Patricia de Barbosa e Cia Typography, was recognized for its excellent technique and printed only newspapers.

Therefore, just as it was possible for Viegas de Menezes and Pimenta e Sal, it is absolutely plausible that Madureira built his press, cast types and made impressions solely from the knowledge acquired in manuals and encyclopedias. It is to be expected, too, that he obtained poor results, since he had no previous experience and had no guidance in the matter.

\section{MADUREIRA'S PRINTED PETITION}

To remain in operation, a letterpress performs jobs of various natures, not just printing newspapers and books. Traditionally, studies of the area are more concerned with the history of books or journalism, and therefore ignore the production of ephemeral prints. In order to be able to say that Madureira's letterpress was effectively put to work it was necessary to find a copy produced by it. Despite the abundance of references, the search for the document itself required determination from the researcher. The so cited (and rarely seen) petition presented by Madureira was found at the Brazilian Historical and Geographical Institute.

It is a double-sided printed folio folded in half, resulting in four pages. The type used is quite irregular, both in its design and spacing, as well as in the form it rests on the baseline, which leads us to conclude that they were indeed cast locally by professionals unskilled in the art of typography. Although a more detailed analysis of the typographic fonts used has not yet been carried out, the presence of different characters for the same glyph is readily noted, that is: multiple models for the lower-case letters "e" and "a", for example. The entire document consists of only one letter size, approximately 16 points. The requirement contains a decorated capital " $\mathrm{S}$ ", and in an attached document there is a capital " $\mathrm{Q}$ ", which follows the style of the text. At the end of both documents, there is the signature "João Francisco de Madureira" in an apparent italic, also printed in a non-uniform way, with some areas more inked and others faded. 
In any case, the requirement is indisputable proof of the operation of João Francisco Madureira's company, therefore the first typography to come into operation in the Province of Grão Pará.

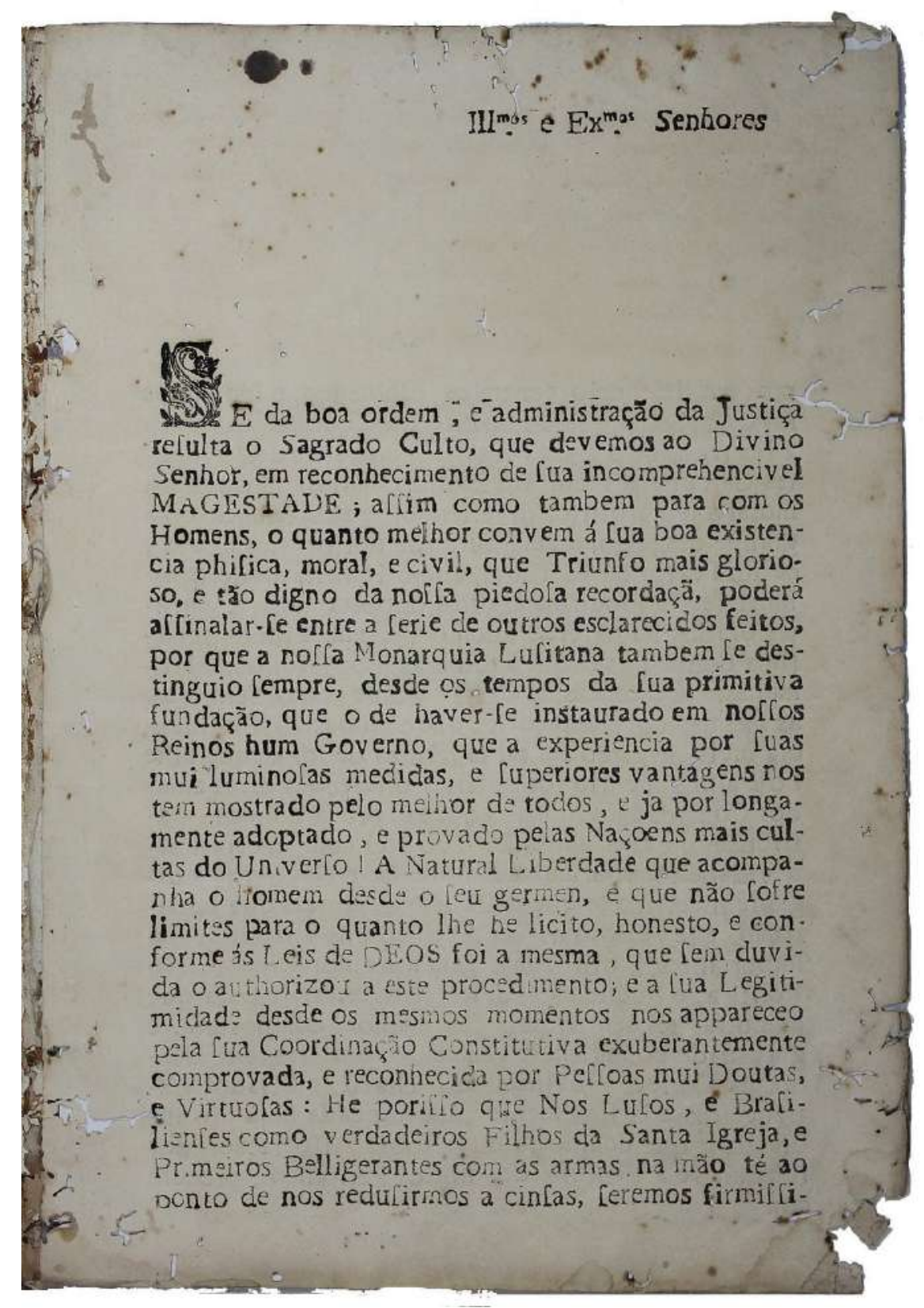

Image 7 - Cover of Madureira's petiton

Source: IHGB 

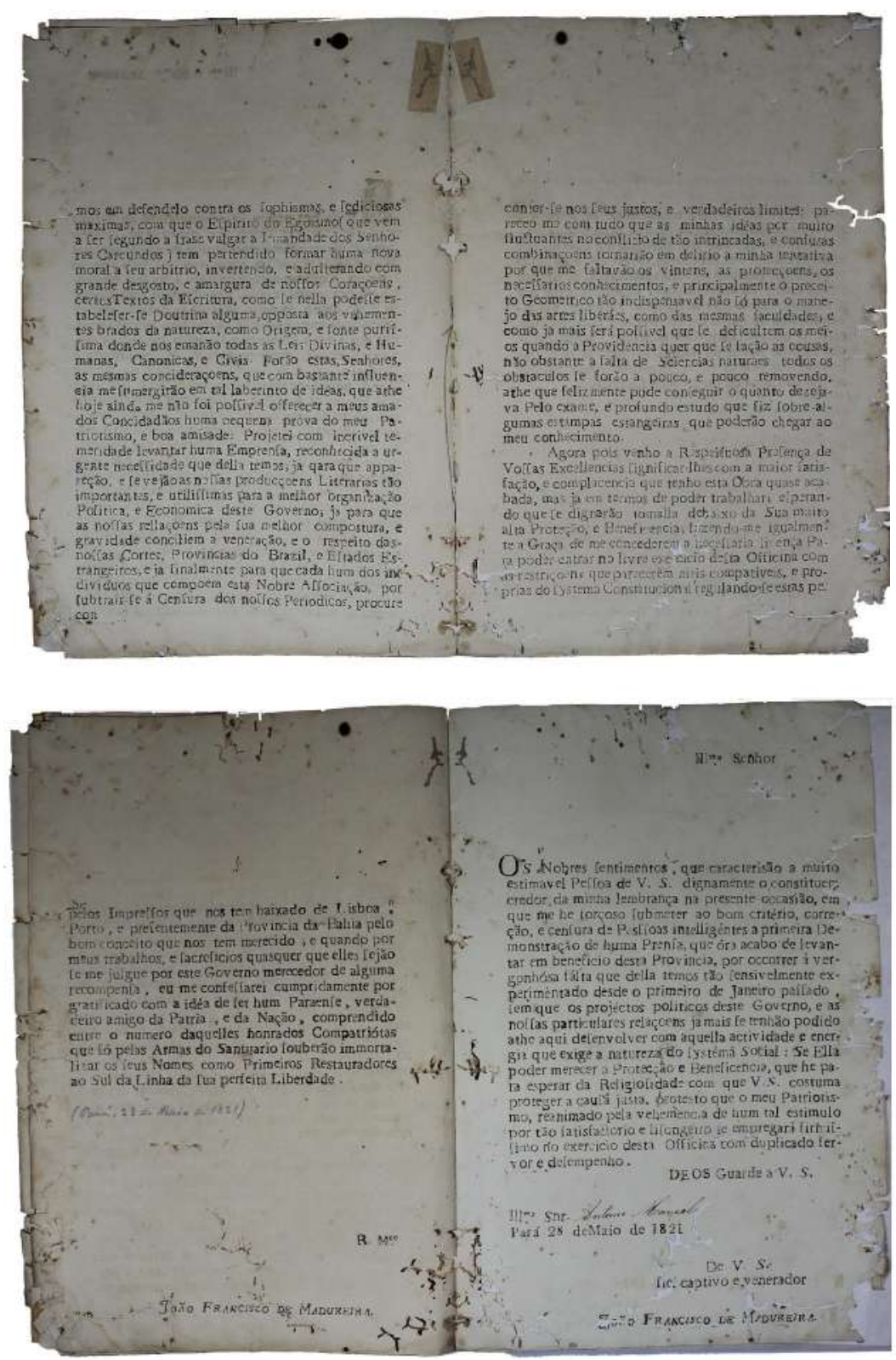

Image 8 - Internal pages of Madureira's requirement (Brazilian Historical and Geographical Institute)

\section{FINAL CONSIDERATIONS}

João Francisco Madureira presented to the Governing Board on May 28, 1821 , a petition printed in a local letterpress, which he himself had built based on 
references from books, requesting permission to start its operations. This fact is presented by Madureira himself, and quoted by narrators at the time, but it has been treated superficially by authors on the subject, important names such as Rizzini (1945) and Hallewel (2005). Perhaps because they disregard ephemeral prints as milestones of the printed culture, or even because they did not access the original document, these authors only reproduced previous information. However, its existence cannot be ignored as proof of the operation of his printing shop.

It is important to highlight the relevance of a printing shop for the time, which is why the subject was included in the historical work of Antonio Ladislao Baena, military man and historian who published Compêndio das Eras da Província do Pará in 1838. It is equally interesting that this author possessed varied information, such as the origin and the amounts of money Madureira borrowed, considering the absence of any documentation on the Madureira press in the $\mathrm{Pu}$ blic Archives, whether that of Pará or the national one, in Rio of January, both of which have been researched for this study.

Surely Madureira, who dedicated a couple of years to deliver this print, deserves the credit for his pioneering work. Particularly since the workshops cited by researchers in the area (the one in Maranhão and the second in Pará), were imported in full from Lisbon, both in terms of equipment and of the professionals who operated the machinery.

From the documents presented, it is possible to affirm that João Francisco Madureira's printing shop, with its press and type casting, was the first workshop to cast types and produce prints in the Amazon in general, and specifically in the province of Grão-Pará, and the fourth to be operational in the country.

The most important aspect in Madureira's achievement is not the construction of the printing press. Presses were common and known for centuries, and documentation on printing techniques was available. The completion of the entire casting process, however, is what is complex, and hardly achievable without the guidance of an official master. That process requires the letter to be carved on the end of a piece of soft steel creating a punch, which originates the matrices that, when inserted in a mold, allow for the casting of multiple equal letters. These letters should compose lines, which make up paragraphs. The set should be uniform, one texture. João Francisco Madureira produced prints in the province of Grão-Pará in May 1821, with the types he created himself, despite the meager resources and difficulties encountered.

Considering that the National Press, in the Rio de Janeiro Court, started with foreign professional type casters and reproduced imported moulds, the set of characters created and used by Madureira can be considered, to this day, the first created by a Brazilian in national territory - followed by those developed by Vie- 
gas de Menezes and Pimenta e Sal in Vila Rica. It can be affirmed, until now, that João Francisco Madureira was the first Brazilian to create a typeface. Studies like this provide new possibilities, and contribute to the recent area of research in Design History: the study of type founders in Brazil.

\section{ACKNOWLEDGEMENTS}

This article is part of the doctorate's research "Impresso no Pará: 1820-1910 - memória gráfica como composição do espírito de época “, supported by FAPERJ.

\section{REFERENCES}

Baena, A. L. M. (1938). Compendio das Eras da Província do Pará. Belém, BR: Typographia Santos \& Santos Menor.

- (1969). Compendio das Eras da Província do Pará. Belém, BR: Universidade Federal do Pará.

Diderot, D.,\& d'Alembert, J. R,. (1751 - 1772). Encyclopédie, ou Dictionnaire raisonné des sciences, des arts et des métiers. Disponível em: http://encyclopédie.eu/index.php. Acesso em 11/07/2016

Eisenstein, E. L. (2009). The Printing Press as an Agent of Change: Communications and Cultural Transformations in Early-modern Europe. Cambridge, UK: Cambridge University Press.

(1998). A Revolução da Cultura Impressa - os Primórdios da Europa Moderna. São Paulo, BR: Editora Ática.

Farias, P. L. (2014). On graphic memory as a strategy for design history. In: Helena Barbosa e Anna Calvera (Ed.) Tradition, transition, trajectories: major or minor influences? Proceedings of the 9th International Committee for Design History and Design Studies]. Aveiro, PT: UA Editora.

Frias, J.M.C. de. ([1866] 2001). Memória sobre a tipografia maranhense. São Paulo, BR: Editora Siciliano.

Hallewell, L. (2005). O Livro no Brasil: sua história. São Paulo, BR: Editora da Universidade de São Paulo.

Instituto Histórico E Geográfico Brasileiro. (1908). Revista do Instituto Histórico e Geográfico Brasileiro. Tomo consagrado à Exposição Commemorativa do Primeiro Centenario da Imprensa Periódica no Brazil, promovida pelo mesmo Instituto. Rio de Janeiro, BR: Imprensa Nacional.

Lima, E. L. C. (2000). F.H. Carls, M.Dreschler, L.Krauss e C. Frese, alemães a serviço da litografia comercial em Recife in Estudos em design, v.2, p 839-847. Novo Hamburgo,BR. 
Lima, E. L. C., \& Fernandes, L. P. (2007). Inovações tecnológicas e o estabelecimento da indústria gráfica brasileira no século XIX. In: Anais do III Congresso Internacional de Design de Informação. Curitiba, BR: SBDI.

Lima, Edna. Lúcia Cunha. (2003). Uma loira forasteira: a cerveja alemã torna-se brasileira. In: Weyrauch, C. S.; Cunha Lima, G.; Héris, A. (Org.). Forasteiros construtores da modernidade. Rio de Janeiro, BR: Editora Terceiro Tempo. - (1998). Cinco décadas de litografia comercial no Recife: Por uma história das marcas de cigarros registradas em Pernambuco, 1875-1924. Dissertação (mestrado) Pontifícia Universidade Católica do Rio de Janeiro, Departamento de Artes.

Madureira, J. F. (1822). Despotismo desmascarado ou a verdade denodada, Lisboa, PT: Typografia de Desiderio Marques Leão. Acesso em 17/02/2012.

Martins, A. L.; \& LUCA, T. R. (2012). História da imprensa no Brasil. São Paulo, BR: Contexto.

Molina, M. M. (2015). História dos jornais no Brasil: Da era colonial à Regência (15001840). São Paulo, SP: Companhia das Letras.

Rayol, D. A. (1865). Motins Políticos, ou historia dos principaes acontecimentos políticos da história da Província do Pará; desde o anno de 1821 até 1835. Rio de Janeiro, BR: Typographia do Imperial Instituto Artístico.

Rizzini, C. (1945). O Livro, o Jornal e a Tipografia no Brasil. 1500-1822. Rio de Janeiro, BR: Livraria Kosmos Editora. . (1977). O jornalismo antes da Tipografia. São Paulo, BR: Companhia Editora Nacional.

Sodré, N. W. (1966). História da Imprensa no Brasil. Rio de Janeiro, BR: Civilização Brasileira. 